\section{C'est le ton qui fait le traitement}

n een ander tijdperk, dat van de Algemene Bijstandswet en de Wet Werk en Bijstand, konden brieven van de Amsterdamse sociale dienst hard aan komen bij de klanten. Sinds een paar jaar kiest de gemeente voor een meer klantvriendelijke toonzetting. Amsterdam heeft lang geworsteld met de juiste toon en terminologie. Dat begint al bij de naam van de gemeentelijke dienst zelf. Tot 2004 deed men bij de gemeente niet moeilijk en heette de sociale dienst gewoon Sociale Dienst, in de volksmond liefkozend afgekort tot 'de soos'. Iedereen wist wat je er mee bedoelde.

\section{Stripheld}

Daarna werd deze Dienst Werk en Inkomen en kon men in het personeelsblad rubrieken lezen als 'de Dwialoog'. Het duurde jaren voordat de nieuwe naam was ingeburgerd. Populair werd deze nooit, ondanks de op een stripheld gebaseerde 'DWI-man!', die de minima moest informeren over gemeentelijke voorzieningen. Vanaf de Participatiewet in 2015 werd de dienst een jaar lang Gemeente Amsterdam Werk Participatie en Inkomen, ofwel GAWPI. Deze aan Elsschot herinnerende naam heeft vreemd genoeg nooit wortel geschoten bij de bevolking. Die bleef spreken van DWI.

In 2016 veranderde de naam opnieuw, dit keer in ResultaatsVerplichte Eenheid Werk Participatie en Inkomen, kortweg RVE WPI. Dat heeft niet lang geduurd. De gemeenteraad nam onlangs een motie aan waarin het begrip RVE tot verbum non grata werd bestempeld. Blijft over WPI, wederom geen term die aanslaat. Ondergetekende merkt dat WPI nog lang niet is ingedaald bij de bijstandspopulatie. Duizenden spreken nog steeds van DWI. Van het jaren zeventig woord 'soos' wordt niet veel meer vernomen.

\section{In zuwang}

Dit kon wel eens gaan veranderen in de nabije toekomst. Sinds de landelijke en plaatselijke projecten om brieven klantvriendelijker te maken, is er een nieuwe stijl in zwang bij de ambtenaren van WPI. Onder het mom van c'est le ton qui fait le traitement worden klanten tegenwoordig uitgenodigd in uiterst beleefde brieven die zelfs enigszins klef te noemen zijn. Maffiataal als 'dit kan gevolgen hebben voor uw uitkering' is voortaan taboe. Brieven beginnen tegenwoordig met 'Hoe gaat het met u?'

Nooit gedacht dat de sociale dienst nog eens zinnen zou gebruiken als 'Ik hoor graag zelf van u hoe het met u gaat' en 'Zijn er dingen die u moeilijk vindt?'

Ondergetekende heeft jarenlang termen gelezen als 'de klant centraal' en 'maatwerk leveren'; loze begrippen die mooi stonden in jaarverslagen en beleidsnota's. Maar zie, ze worden in Amsterdam eindelijk waargemaakt. Van de klanten krijgt WPI ook veel waardering voor de respectvolle bejegening. Nu de naam van de dienst zelf nog.

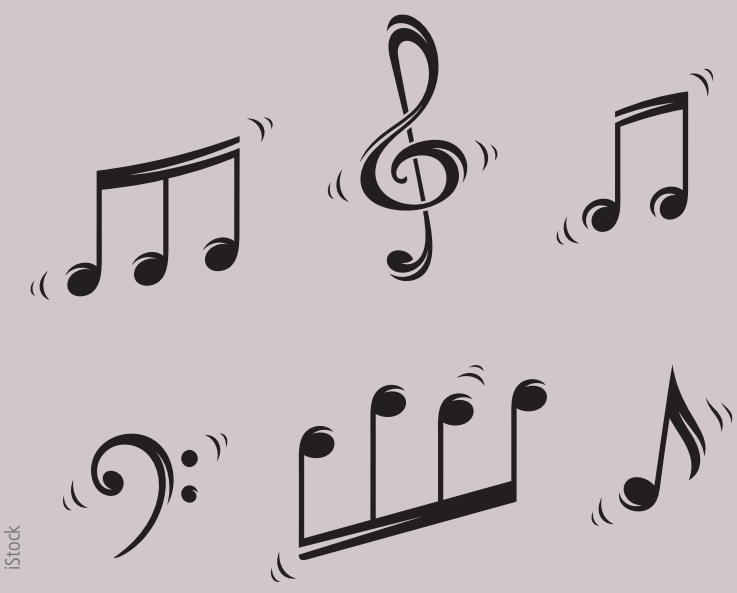

'Het is de toon die de behandeling bepaalt'
Nooit gedacht dat de sociale dienst nog eens zinnen zou gebruiken als: 'Zijn er dingen die u moeilijk vindt?'

\title{
Martin Brandwagt,
}

Participatieraad Amsterdam 